\title{
Effect of Resistance Training and Diet Intake on Spleen Structure of Ovariectomized Wistar Rats
}

\author{
Erika Steffany dos Santos Santana ${ }^{1}$ \\ Ricardo Aparecido Baptista Nucci ${ }^{1,2}$ \\ ${ }^{1}$ Department of Aging Sciences, São Judas Tadeu University, São \\ Paulo, Brazil \\ ${ }^{2}$ Department of Pathology, University of São Paulo Medical School, \\ São Paulo, Brazil \\ ${ }^{3}$ Laboratory of Clinical Analysis, ABC District Medical School, Santo \\ André, Brazil \\ ${ }^{4}$ Department of Pharmaceutical Sciences, Federal University of São \\ Paulo, São Paulo, Brazil \\ ${ }^{5}$ Dante Pazzanese Institute of Cardiology, São Paulo, Brazil
}

\author{
Address for correspondence Ricardo Aparecido Baptista \\ Nucci, PhD, Department of Pathology, University of São Paulo \\ Medical School, Av. Dr. Arnaldo, 455 Cerqueira César, São Paulo, \\ Brazil 01246-903 (e-mail: nucci.ricardo.ab@gmail.com).
}

\begin{abstract}
Keywords

- aging

- diet

- exercise
\end{abstract}

\section{Introduction}

Menopause is accompanied with homeostatic imbalance in women's health. ${ }^{1}$ Postmenopausal women may have a high risk of osteoporosis ${ }^{2,3}$ and cardiac disfunctions. ${ }^{4,5}$ However, exercise is an effective therapy to maintain physiological balance in postmenopausal women, preventing a range of pathologies (e.g., osteoporosis, hypertension, high glycemia).$^{6-9}$ Additionally, resistance training, along with diet, is a

published online August 5, 2021
DOI https://doi.org/ $10.1055 / \mathrm{s}-0041-1732812$ ISSN 2582-4287 key therapy to maintain lean body mass, which declines with aging and hormone dysfunction. ${ }^{10}$

Exercise is also known to provide positive immune changes, especially in the spleen. ${ }^{11,12}$ The spleen is the largest secondary immune organ in the body, which contains a reserve of red cells, leucocytes, and platelets. ${ }^{13}$ Additionally, there are two main types of tissue in spleen anatomy: a red pulp, which is vascular, and has the large, thin-walled sinuses, which are red due to the large number of erythrocytes, and

(c) 2021. Nitte (Deemed to be University).

This is an open access article published by Thieme under the terms of the Creative Commons Attribution-NonDerivative-NonCommercial-License, permitting copying and reproduction so long as the original work is given appropriate credit. Contents may not be used for commercial purposes, or adapted, remixed, transformed or built upon. (https://creativecommons.org/licenses/by-nc-nd/4.0/). Thieme Medical and Scientific Publishers Pvt. Ltd. A-12, 2nd Floor, Sector 2, Noida-201301 UP, India 
a white pulp that contains lymphoid aggregations, mostly lymphocytes, and macrophages which are arranged around the arteries. ${ }^{13}$ Although, active contraction of the spleen can contribute a substantial addition to total blood volume and mobilization of immune cells during exercise, ${ }^{12}$ there is still a lack of studies on the effects of aging on spleen structure with or without an exercise routine, along with animal or vegetable protein diet.

Thus, we aimed to analyze the effects of ovariectomy and resistance training on spleen structure of animals submitted to different diet protocols.

\section{Materials and Methods}

The Institutional Animal Care and Use Committee of the university approved the experimental protocol (protocol A-00610/2010) and all procedures were in accordance with the guiding principles of the National Institute of Health Guide for the Care and Use of Laboratory Animals. A total of 64 female Wistar rats (Rattus norvegicus, 21 days of life) were used from the Animal Center of the São Judas Tadeu University, São Paulo, Brazil. During experimentation, animals were housed in boxes of polypropylene and kept under controlled environmental conditions with access to water and standard chow exclusively from vegetable sources (NUVILAB CR1, produced by NUVITAL Nutrientes Ltda, Curitiba, Paraná ).

Animals were divided into eight groups ( $n=8 /$ per group): sedentary and nonovariectomized animals plus vegetable protein diet (CVS) or animal protein diet (CAS); trained and nonovariectomized rats plus vegetable protein diet (CVT) or animal protein diet (CT); sedentary and ovariectomized groups plus vegetable protein diet (VOS) or animal protein diet (AOS); and trained and ovariectomized animals plus vegetable protein diet (VOT) or animal protein diet (AOT).

\section{Experimental Procedures}

Resistance training (RT) started at 14 months of age using a vertical ladder. ${ }^{14-17}$ In the RT protocol for the selected groups (CVT, VOT, CT, AOT), the initial load was established as 75\% of the body weight of each animal (three sessions per week on alternate days for 12 weeks). Each week, animals were weighed for correcting the initial load. Additionally, at 14 months of age, we initiated a diet protocol until euthanasia. Those animals selected for the vegetable diet groups (CVS, CVT, VOS, and VOT) maintained the standard chow from NUVITAL. However, the groups submitted to animal protein diet had been fed with a chow specially formulated for this study by the Rhoster Laboratory (Rhosterlab, Rhoster Ltda, Araçoiaba da Serra, Sau Paulo, Brazil), as previously described. ${ }^{16,17}$

At the end of the experimental protocols, all animals were anesthetized with an intraperitoneal injection of thiopental ( $40 \mathrm{mg} / \mathrm{kg}$ body weight, Sigma, St. Louis, MO, United States). Spleen samples were removed and fragments were fixed in $10 \%$ buffered formalin. Thus, material was dehydrated in increasing series of alcohols, diaphanized in xylene, embedded in paraffin, sectioned in nonserial slices of $6 \mu \mathrm{m}$, and stained with hematoxylin and eosin (HE) for structure analysis and picrosirius red for collagen quantification at light microscopy, with a polarized filter to distinguish the collagen fibers.

Forty photomicrographs were acquired per animal (i.e., 20 images per technique) with a light microscope (Zeiss, $\times 100$ magnifications). The analysis of densities of both red pulp and white pulp, as well as, blood vessels, trabeculae, capsule, follicles, and collagen fibers, were performed by stereology, with a test system of 252 points, using Image J software (National Institutes of Health, United States). ${ }^{18}$ The follicle area $\left(\mu \mathrm{m}^{2}\right)$ and mean diameter $(\mu \mathrm{m})$ analysis were performed using the outline tool from Axio Vision software (Carl Zeiss Microscopy, LLC, New York, United States).

\section{Statistical Analysis}

Data are presented as mean and standard deviation (mean \pm SD). We performed one-way analysis of variance (ANOVA) (post hoc Newman-Keuls) for data comparison between groups, with statistical differences set at $p \leq 0.05$. For data management, GraphPad Prism 5.0 software (GraphPad Prism Inc., San Diego, California), was used.

\section{Results}

Our results showed an increase of body weight in ovariectomized animals (-Table 1). However, no significant variation in both spleen weight and spleen/body weight were observed between groups.

We observed, see - Table 1, a significant decrease $(p<0.05)$ of the red pulp with both exercise and menopause when compared with CVS. On the other hand, menopause and resistance exercises in vegetable protein diet significantly increased $(p<0.05)$ the white pulp when compared with CVS. However, the animal protein diet groups submitted to both resistance training and estrogen deprivation were significantly decreased $(p<0.05)$ when compared with the other groups. Additionally, sedentary ovariectomized animals submitted to animal protein diet slightly decreased $(p<0.05)$ spleen trabeculae when compared with CVS, CVT, and VOT. Regarding spleen capsule, we observed a slight decrease $(p<0.05)$ in AOS when compared with VOS group. However, blood vessels did not significantly change between the groups. We observed an increase $(p<0.05)$ in AOT follicle density, area $\left(\mu \mathrm{m}^{2}\right)$, and diameter $(\mu \mathrm{m})$ when compared with groups submitted to resistance training (-Table 2). Representative images are shown in -Fig. 1.

Finally, collagen analysis showed a great variation $(p<0.05)$ in both type I and type III collagen fibers in red pulp, white pulp, and spleen capsule from the animal protein diet groups when compared with vegetable protein diet groups (-Fig. 2).

\section{Discussion}

Our results demonstrated that both menopause and RT alter spleen structure depending on the diet intake. Venkatraman and Fernandes ${ }^{6}$ showed a decrease in immune reactivity with increasing age which may reflect multiple events 
Table 1 Weight (body, spleen, spleen/body weight) and stereological analysis (red pulp, white pulp, blood vessels, trabeculae, capsule, and follicle) between the groups

\begin{tabular}{|c|c|c|c|c|c|c|c|c|}
\hline \multirow[t]{2}{*}{ Variables } & \multicolumn{8}{|l|}{ Groups } \\
\hline & CVS & CVT & VOS & VOT & CAS & CT & AOS & AOT \\
\hline \multicolumn{9}{|l|}{ Weight } \\
\hline $\begin{array}{l}\text { Body weight } \\
\text { (g) }\end{array}$ & $\begin{array}{l}274.5 \pm \\
19.16\end{array}$ & $\begin{array}{l}260.0 \pm \\
33.17\end{array}$ & $\begin{array}{l}300.8 \pm \\
53.05\end{array}$ & $\begin{array}{l}361.0 \pm \\
76.84^{\mathrm{ab}}\end{array}$ & $\begin{array}{l}264.5^{ \pm} \\
19.26^{d}\end{array}$ & $\begin{array}{l}256.3 \pm \\
34.00^{\mathrm{d}}\end{array}$ & $\begin{array}{l}353.6 \pm \\
48.62^{\text {bef }}\end{array}$ & $334.4 \pm 46.40$ \\
\hline $\begin{array}{l}\text { Spleen } \\
\text { weight }(\mathrm{g})\end{array}$ & $\begin{array}{l}0.82 \pm \\
0.12\end{array}$ & $\begin{array}{l}0,71 \pm \\
0.07\end{array}$ & $\begin{array}{l}0,71 \pm \\
0.11\end{array}$ & $\begin{array}{l}0,91 \pm \\
0.16\end{array}$ & $\begin{array}{l}0.75 \pm \\
0.14\end{array}$ & $\begin{array}{l}0.64 \pm \\
0.11\end{array}$ & $0.76 \pm 0.06$ & $0.73 \pm 0.10$ \\
\hline $\begin{array}{l}\text { Spleen/body } \\
\text { weight (\%) }\end{array}$ & $\begin{array}{l}0.30 \pm \\
0.05\end{array}$ & $\begin{array}{l}0.27 \pm \\
0.04\end{array}$ & $\begin{array}{l}0.24 \pm \\
0.04\end{array}$ & $\begin{array}{l}0.26 \pm \\
0.07\end{array}$ & $\begin{array}{l}0.28 \pm \\
0.04\end{array}$ & $\begin{array}{l}0.24 \pm \\
0.02\end{array}$ & $0.22 \pm 0.03$ & $0.22 \pm 0.05$ \\
\hline \multicolumn{9}{|l|}{ Stereology } \\
\hline Red pulp (\%) & $\begin{array}{l}70.60 \pm \\
11.93\end{array}$ & $\begin{array}{l}48.91 \pm \\
8.94^{\mathrm{a}}\end{array}$ & $\begin{array}{l}37.14 \pm \\
6.00^{\mathrm{ab}}\end{array}$ & $\begin{array}{l}46.09 \pm \\
14.93^{\mathrm{a}}\end{array}$ & $\begin{array}{l}51.48 \pm \\
11.47^{a c}\end{array}$ & $\begin{array}{l}57.56 \pm \\
6.80^{\text {ac }}\end{array}$ & $\begin{array}{l}58.63 \pm \\
13.80^{c}\end{array}$ & $56.02 \pm 10.12^{\mathrm{ac}}$ \\
\hline $\begin{array}{l}\text { White pulp } \\
(\%)\end{array}$ & $\begin{array}{l}24.74 \pm \\
10.57\end{array}$ & $\begin{array}{l}46.93 \pm \\
10.46^{a}\end{array}$ & $\begin{array}{l}58.52 \pm \\
9.55^{\mathrm{a}}\end{array}$ & $\begin{array}{l}49.61 \pm \\
14.03^{a}\end{array}$ & $\begin{array}{l}38.78 \pm \\
12.02^{c}\end{array}$ & $\begin{array}{l}33.62 \pm \\
6.97^{\text {bcd }}\end{array}$ & $\begin{array}{l}19.00 \pm \\
14.79^{\text {bcdef }}\end{array}$ & $18.60 \pm 15.33^{\text {bcdef }}$ \\
\hline $\begin{array}{l}\text { Blood vessels } \\
(\%)\end{array}$ & $\begin{array}{l}1.64 \pm \\
1.15\end{array}$ & $\begin{array}{l}1.37 \pm \\
2.34\end{array}$ & $\begin{array}{l}1.93 \pm \\
4.24\end{array}$ & $\begin{array}{l}1.55 \pm \\
2.96\end{array}$ & $\begin{array}{l}0.25 \pm \\
0.86\end{array}$ & $\begin{array}{l}0.01 \pm \\
0.00\end{array}$ & $0.01 \pm 0.00$ & $1.25 \pm 3.22$ \\
\hline $\begin{array}{l}\text { Trabeculae } \\
(\%)\end{array}$ & $\begin{array}{l}2.48 \pm \\
1.74\end{array}$ & $\begin{array}{l}1.80 \pm \\
1.76\end{array}$ & $\begin{array}{l}1.06 \pm \\
1.19\end{array}$ & $\begin{array}{l}1.64 \pm \\
1.80\end{array}$ & $\begin{array}{l}1.46 \pm \\
1.33\end{array}$ & $\begin{array}{l}0.90 \pm \\
0.88\end{array}$ & $0.08 \pm 0.30^{\mathrm{abd}}$ & $1.12 \pm 1.30$ \\
\hline Capsule (\%) & $\begin{array}{l}0.05 \pm \\
0.12\end{array}$ & $\begin{array}{l}0.06 \pm \\
0.16\end{array}$ & $\begin{array}{l}0.03 \pm \\
0.10\end{array}$ & $\begin{array}{l}0.48 \pm \\
0.73\end{array}$ & $\begin{array}{l}0.38 \pm \\
0.94\end{array}$ & $\begin{array}{l}1.06 \pm \\
1.44\end{array}$ & $1.09 \pm 1.49$ & $0.65 \pm 0.97$ \\
\hline Follicle (\%) & $\begin{array}{l}0.54 \pm \\
0.51\end{array}$ & $\begin{array}{l}0.93 \pm \\
0.60\end{array}$ & $\begin{array}{l}1.26 \pm \\
0.93\end{array}$ & $\begin{array}{l}1.08 \pm \\
1.76\end{array}$ & $\begin{array}{l}5.89 \pm \\
3.47\end{array}$ & $\begin{array}{l}5.29 \pm \\
2.71\end{array}$ & $\begin{array}{l}20.49 \pm \\
10.77^{\text {abcdef }}\end{array}$ & $21.99 \pm 15.09^{\text {abcde }}$ \\
\hline
\end{tabular}

Abbreviations: CVS, sedentary and nonovariectomized animals plus vegetable protein diet; CAS, sedentary and nonovariectomized animals plus animal protein diet; CVT, trained and nonovariectomized rats plus vegetable protein diet; $C T$, trained and nonovariectomized rats plus animal protein diet; VOS, sedentary and ovariectomized groups plus vegetable protein diet; AOS, sedentary and ovariectomized groups plus animal protein diet; VOT, trained and ovariectomized animals plus vegetable protein diet; AOT, trained and ovariectomized animals plus animal protein diet. Values are expressed as mean \pm standard deviation (SD).

${ }^{a} p<0.05$ versus CVS.

${ }^{\mathrm{b}} p<0.05$ versus CVT.

${ }^{c} p<0.05$ versus VOS.

${ }^{\mathrm{d}} p<0.05$ versus VOT.

${ }^{\mathrm{e}} \mathrm{p}<0.05$ versus CAS.

${ }^{f} p<0.05$ versus $C T$.

${ }^{9} p<0.05$ versus AOS.

Table 2 Area $\left(\mu \mathrm{m}^{2}\right)$ and diameter $(\mu \mathrm{m})$ of follicle between the groups

\begin{tabular}{|l|l|l|l|l|l|l|l|l|}
\hline \multirow{2}{*}{ Variables } & \multicolumn{9}{|c|}{ Groups } \\
\cline { 2 - 9 } & CVS & CVT & VOS & VOT & CAS & CT & AOS & AOT \\
\hline $\begin{array}{l}\text { Follicle area } \\
\left(\mu \mathrm{m}^{2}\right)\end{array}$ & $275,900 \pm$ & $255,600 \pm$ & $340,600 \pm$ & $229,200 \pm$ & $247,900 \pm$ & $188,700 \pm$ & $317,900 \pm$ & $375,200 \pm$ \\
\hline $\begin{array}{l}\text { Follicle diam- } \\
\text { eter }(\mu \mathrm{m})\end{array}$ & 198,000 & 193,900 & 197,300 & 147,200 & 175,300 & $147,700^{c}$ & $256,700^{f}$ & $322,400^{\text {bdf }}$ \\
\hline
\end{tabular}

Abbreviations: CVS, sedentary and nonovariectomized animals plus vegetable protein diet; CAS, sedentary and nonovariectomized animals plus animal protein diet; CVT, trained and nonovariectomized rats plus vegetable protein diet; CT, trained and nonovariectomized rats plus animal protein diet; VOS, sedentary and ovariectomized groups plus vegetable protein diet; AOS, sedentary and ovariectomized groups plus animal protein diet; VOT, trained and ovariectomized animals plus vegetable protein diet; AOT, trained and ovariectomized animals plus animal protein diet.

Values are expressed as mean \pm standard deviation (SD).

${ }^{a} p<0.05$ versus CVS.

${ }^{\mathrm{b}} p<0.05$ versus CVT.

${ }^{c} p<0.05$ versus VOS.

${ }^{\mathrm{d}} p<0.05$ versus VOT.

${ }^{\mathrm{e}} \mathrm{p}<0.05$ versus CAS.

${ }^{\mathrm{f}} p<0.05$ versus $C \mathrm{C}$.

${ }^{9} p<0.05$ versus AOS.

affecting cell proliferation and differentiation, leading to a reduction in cell number and function within one or more cell populations. On the other hand, it has been shown that exercise training can increase macrophage activity in mice of different ages. ${ }^{19,20}$ However, not all functions are enhanced by exercise, which brings up the possibility that exercise, and perhaps other stressors, activate macrophages for effector functions while downregulating accessory cell functions. 

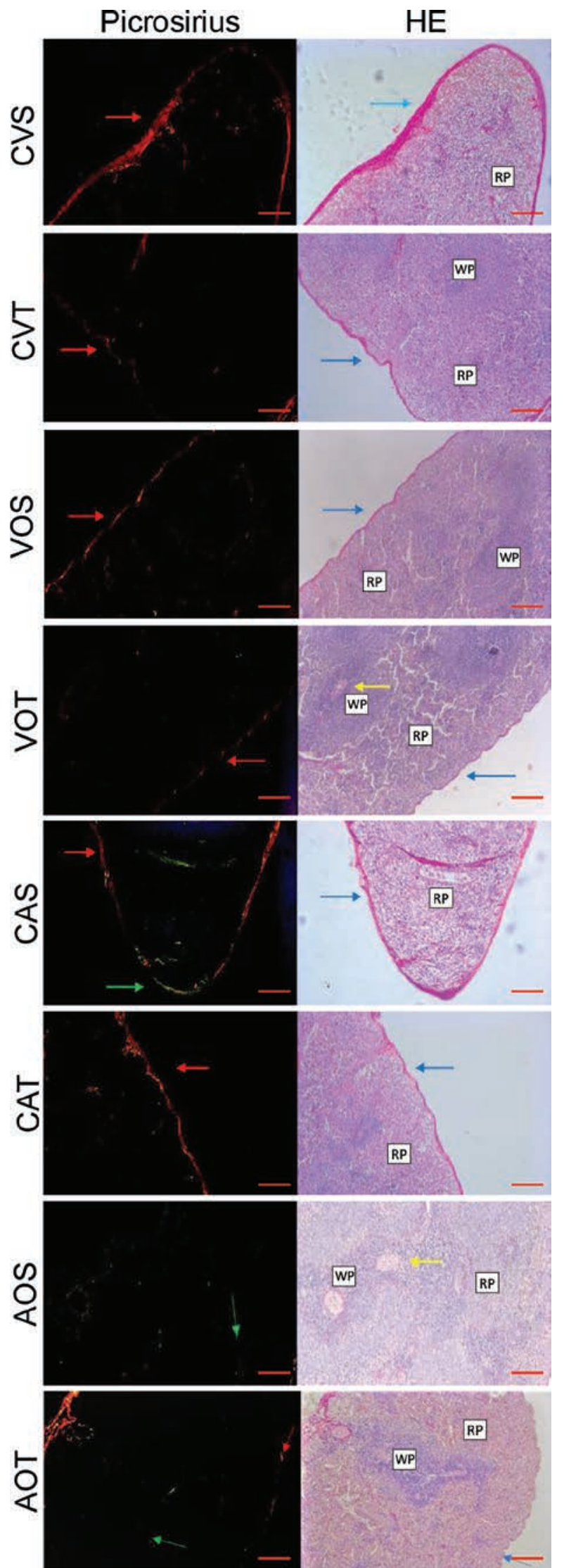

Fig. 1 Representative images between the groups with picrosirius red (under polarized filter) and hematoxylin and eosin (HE) staining techniques. Red arrow: collagen fiber type I. Green arrow: collagen fiber type III. Blue arrow: capsule. Yellow arrow: blood vessel. Abbreviations: RP, red pulp; WP, white pulp. Scale bar $=50 \mu \mathrm{m}$.
However, these mechanisms may depend on exercise-induced changes associated with diet intake in neuroendocrine factors which modulate the splenic microanatomy (e.g., follicle) by a process that involves the hypothalamic-pituitary-adrenal axis.. ${ }^{20,21}$ Thus, Venkatraman and Fernandes ${ }^{6}$ suggested that moderate exercise should help to reverse the adverse effects of aging upon the immune system by increasing the production of endocrine hormones which may contribute to less accumulation of autoreactive immune cells by enhancing the programmed cell death. In addition, Vider and colleagues ${ }^{22}$ highlighted the relation between exhaustive exercise, oxidative stress, the protective capacity of the antioxidant defense system and cellular immune. After a short-term bout of exhaustive exercise, immune system was characterized by acute phase response, which was accompanied with oxidative stress and a suppression of the cellular immunity 30 minutes after exercise.

We observed that diet intake may be a critical factor in immunological homeostasis. Interestingly, previous studies reported that an exercise routine accompanied with dietary intake may modulate the immune response in which a low-fat high-carbohydrate diet accompanied with vigorous exercise increases inflammatory and decreases anti-inflammatory immune factors, depresses antioxidants, and negatively affects blood lipoprotein ratios. ${ }^{23}$ On the other hand, an experimental study with mice demonstrated that both aerobic exercise and caloric restriction were able to counterbalance the deleterious effects induced by a high-fat diet. ${ }^{20}$ Our study highlight that the spleen structure changes in mainly sedentary or trained animals submitted to animal protein based diet associated with estrogen deprivation.

Although it is known that there is collagen fiber deposition in the spleen with age, ${ }^{24}$ there is still unclear evidences about the effects of diet intake in ovariectomized animals submitted to RT. Our results demonstrated that both RT and diet intake, mainly animal protein-based, affect most the type III collagen fibers which may decrease spleen compliance, limiting its expansion and leading to a gradual reduction in splenic size and blood flow. ${ }^{24}$

However, our results should be examined considering the study limitations. We did not analyze the complete blood count (hematocrit, hemoglobin, platelets, red and white blood cells). Additionally, molecular techniques could potentially identify the mechanisms related to RT and each diet in the immunological system. Although our study has limitations, it also has some advantages. We analyzed the spleen structure using standardized techniques for quantitative evaluation. ${ }^{16,17}$ Additionally, our research protocols (RT and diet intake) were in accordance with previous described for ovariectomized animals. ${ }^{16,17}$

\section{Conclusion}

In summary, RT associated with diet intake may play a key factor to maintain spleen's immune responses across age. Our results showed that vegetable protein-based diet associated with RT may modulate spleen structure maintaining the immunological homeostasis. On the other hand, we suggest 

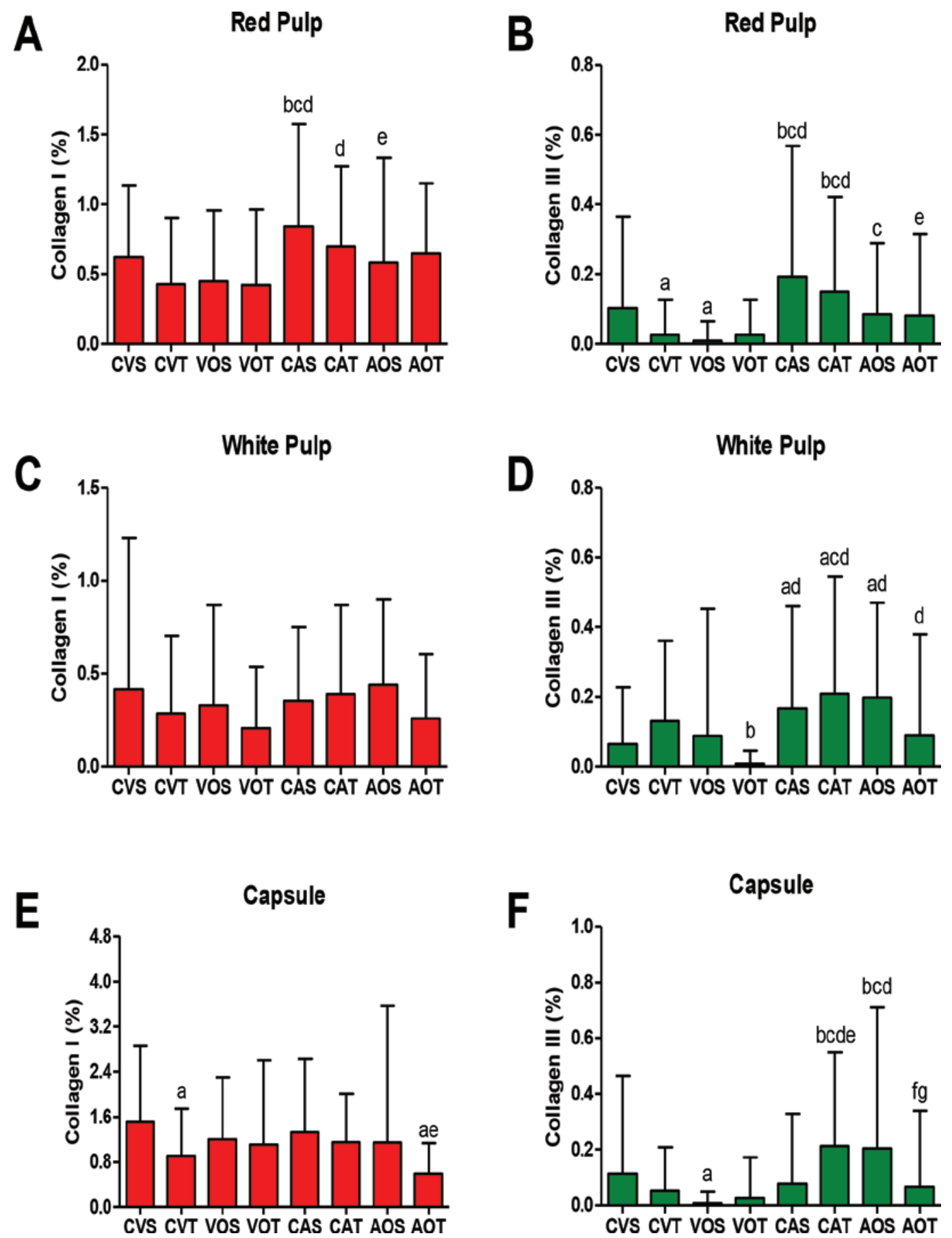

Fig. 2 Quantitative analysis of collagen fibers type I (A, C, E) and type III (B, D, F) in red pulp (A, B), white pulp (C, D), and spleen capsule $(\mathrm{E}, \mathbf{F}) .{ }^{\mathrm{a}} p<0.05$ versus CVS; ${ }^{b} p<0.05$ versus CVT; ${ }^{c} p<0.05$ versus VOS; ${ }^{d} p<0.05$ versus VOT; ${ }^{e} p<0.05$ versus CAS; ${ }^{f} p<0.05$ versus $C T ;{ }^{p} p<$ 0.05 versus $A O S$.

that animal protein diet may decrease the immune response in ovariectomized animals despite an exercise routine. However, the design of our study was directed toward a morphological analysis of the spleen, which limited us in terms of biochemical and molecular analyzes. Thus, further studies are needed to corroborate our findings through physiological and molecular techniques regarding immune response.

Authors' Contributions

E.S.D.: Investigation, writing-review and editing.

C.A.D.: Investigation, writing-review and editing.
F.I.A.L.: Investigation, writing-review and editing.

R.A.B.N.: Data curation, formal analysis, visualization, writing-review and editing.

F.L.A.F.: Resources, supervision, validation, writing-original draft.

L.B.M.M.: Conceptualization, methodology, project administration, writing-original draft.

Note

The Institutional Animal Care and Use Committee of the university approved the experimental protocol (protocol 
A-00610/2010) and all procedures were in accordance with the guiding principles of the National Institute of Health Guide for the Care and Use of Laboratory Animals. A total of 64 female Wistar rats (Rattus norvegicus, 21 days of life) were used from the Animal Center of the São Judas Tadeu University, São Paulo, Brazil.

\section{Conflict of Interest}

None declared.

\section{References}

1 Monteleone P, Mascagni G, Giannini A, Genazzani AR, Simoncini T. Symptoms of menopause-global prevalence, physiology and implications. Nat Rev Endocrinol 2018;14(4):199-215

2 North American Menopause Society. Management of osteoporosis in postmenopausal women: 2006 position statement of The North American Menopause Society. Menopause 2006;13(3):340-367, quiz 368-369

3 Zhu D, Li X, Macrae VE, Simoncini T, Fu X. Extragonadal effects of follicle-stimulating hormone on osteoporosis and cardiovascular disease in women during menopausal transition. Trends Endocrinol Metab 2018;29(8):571-580

4 Colditz GA, Willett WC, Stampfer MJ, Rosner B, Speizer FE, Hennekens $\mathrm{CH}$. Menopause and the risk of coronary heart disease in women. N Engl J Med 1987;316(18):1105-1110

5 Khan ZA, Janssen I, Mazzarelli JK, et al. Serial studies in subclinical atherosclerosis during menopausal transition (from the Study of Women's Health Across the Nation. Am J Cardiol 2018;122(7):1161-1168

6 Venjatraman JT, Fernandes G. Exercise, immunity and aging. Aging (Milano 1997;9(1-2):42-56

7 Boulé NG, Haddad E, Kenny GP, Wells GA, Sigal RJ. Effects of exercise on glycemic control and body mass in type 2 diabetes mellitus: a meta-analysis of controlled clinical trials. JAMA 2001;286(10):1218-1227

8 Whelton SP, Chin A, Xin X, He J. Effect of aerobic exercise on blood pressure: a meta-analysis of randomized, controlled trials. Ann Intern Med 2002;136(7):493-503

9 Martyn-St James M, Carroll S. A meta-analysis of impact exercise on postmenopausal bone loss: the case for mixed loading exercise programmes. Br J Sports Med 2009;43(12):898-908

10 Wolff I, van Croonenborg JJ, Kemper HCG, Kostense PJ, Twisk JWR. The effect of exercise training programs on bone mass: a meta-analysis of published controlled trials in preand postmenopausal women. Osteoporos Int 1999;9(1):1-12

11 Nieman DC. Current perspective on exercise immunology. Curr Sports Med Rep 2003;2(5):239-242

12 Shephard RJ. Responses of the human spleen to exercise. J Sports Sci 2016;34(10):929-936

13 Cesta MF. Normal structure, function, and histology of the spleen. Toxicol Pathol 2006;34(5):455-465

14 Lee S, Barton ER, Sweeney HL, Farrar RP. Viral expression of insulin-like growth factor-I enhances muscle hypertrophy in resistance-trained rats. J Appl Physiol (1985 2004;96(3):1097-1104

15 Nucci RAB, Teodoro ACS, Krause Neto W, et al. Effects of resistance training on liver structure and function of aged rats. Aging Male 2018;21(1):60-64

16 Cury JCS, Encinas JA, Nucci RAB, et al. Effects of different diet intake and resistance training on left ventricle remodeling in ovariectomized rats. Comp Clin Pathol 2019;28:1797-1803

17 Braggion GF, Ornelas EM, Cury JCS, et al. Remodeling of the soleus muscle of ovariectomized old female rats submitted to resistance training and different diet intake. Acta Histochem 2020;122(5):151570

18 Schneider CA, Rasband WS, Eliceiri KW. NIH Image to ImageJ: 25 years of image analysis. Nat Methods 2012;9(7):671-675

19 Woods J, Lu Q, Ceddia MA, Lowder T. Special feature for the Olympics: effects of exercise on the immune system: exercise-induced modulation of macrophage function. Immunol Cell Biol 2000;78(5):545-553

20 Wasinski F, Bacurau RF, Moraes MR, et al. Exercise and caloric restriction alter the immune system of mice submitted to a high-fat diet. Mediators Inflamm 2013;2013:395672

21 Moita L, Lustosa MF, Silva ATT, et al. Moderate physical training attenuates the effects of perinatal undernutrition on the morphometry of the splenic lymphoid follicles in endotoxemic adult rats. Neuroimmunomodulation 2011;18(2):103-110

22 Vider J, Lehtmaa J, Kullisaar $\mathrm{T}$, et al. Acute immune response in respect to exercise-induced oxidative stress. Pathophysiology 2001;7(4):263-270

23 Venkatraman JT, Leddy J, Pendergast D. Dietary fats and immune status in athletes: clinical implications. Med Sci Sports Exerc 2000;32(7(Suppl):S389-S395

24 Rodrigues CJ, Sacchetti JCL, Rodrigues AJ Jr. Age-related changes in the elastic fiber network of the human splenic capsule. Lymphology 1999;32(2):64-69 